\title{
AGRONOMIC AND MORPHOLOGICAL CHARACTERIZATION OF LIPPIA (VERBENACEAE) SPECIES NATIVE FROM BRAZILIAN SEMIARID REGION
}

Ariana Reis Messias Fernandes de Oliveira ${ }^{1}$, Lenaldo Muniz Oliveira ${ }^{2}$, José Floriano Barea Pastore ${ }^{3}$, Tânia Regina dos Santos Silva ${ }^{2}$, Larissa Correa do Bonfim Costa ${ }^{4}$

${ }^{1}$ Instituto Federal de Educação, Ciência e Tecnologia Baiano - Uruçuca-Bahia. E-mail: rylreis@ gmail.com

${ }^{2}$ Universidade Estadual de Feira de Santana - Bahia. E-mail: lenaldo@uefs.br, tanialantana@gmail.com

${ }^{3}$ Universidade Federal de Santa Catarina. E-mail: jfpastore@ hotmail.com

${ }^{4}$ Universidade Estadual de Santa Cruz, Ilhéus - Bahia. E-mail: larissa@ uesc.edu.br

\section{ABSTRACT}

The genus Lippia $\mathrm{L}$. is represented by several aromatic species, producing essential oils with biological activity, especially antimicrobial. The semiarid region of Bahia contains several Lippia species that could be economically exploited. This study aimed to characterize morphological and agronomic traits of four species of Lippia native from this semiarid region. We conducted quantitative and qualitative morphological characterizations, and evaluated the characters of stem, leaf and inflorescence; in addition to the agronomic characterization, with the fresh and dry matter of inflorescences, we evaluated leaves and stem and essential oil content and yield. The results showed morphological differences between the species for all traits evaluated, except for the number of flowers per inflorescence. The agronomical characterization showed differences for all measured characters, and the species Lippia lasiocalycina was distinguished by the essential oil yield.

Keywords: Lippia insignis, L. lasiocalycina, L. bromleyana, L. thymoides

\section{CARACTERIZAÇÃO MORFOLÓGICA E AGRONÔMICA DE ESPÉCIES DE LIPPIA (VERBENACEAE) NATIVAS DO SEMIÁRIDO BRASILEIRO}

\section{RESUMO}

O gênero Lippia L. é representado por diversas espécies aromáticas, produtoras de óleos essenciais com atividade biológica, principalmente antimicrobiana. $\mathrm{O}$ semiárido apresenta grande riqueza de espécies de Lippia, que potencialmente podem vir a ser exploradas economicamente. Este 
trabalho teve como objetivo realizar a caracterização morfológica e agronômica de quatro espécies desse gênero, nativas do semiárido baiano. Foram realizadas caracterizações morfológicas quantitativas e qualitativas, nas quais foram avaliados os caracteres de caule, folha e inflorescência; além da caracterização agronômica, onde se avaliou a massa fresca e seca das inflorescências, folhas e caule, teor e rendimento de óleo essencial. Os resultados demonstraram diferenças morfológicas entre as espécies em todas as características avaliadas, com exceção apenas ao número de flores por inflorescência. Na caracterização agronômica foram encontradas diferenças em todos os caracteres avaliados, sendo que a espécie Lippia lasiocalycina se destacou em relação à variável rendimento de óleo essencial.

Palavras-chave: Lippia insignis, L. lasiocalycina, L. bromleyana, L. thymoides

\section{INTRODUCTION}

The Verbenaceae family comprises medicinal and ornamental species, as well as timber species, and are, therefore, economically important (MELO et al. 2010). Lippia L. is one of the largest genera of Verbenaceae with the major diversity in Brazil. The nearly 100 species (O'LEARY et al. 2012), most of them, 82 in total, occur in Brazil, and 60 species are endemic of Brazilian territory (BFG, 2015). This genus includes a number of aromatic and medicinal plants with economic potential for the pharmaceutical and cosmetics industries due to their essential oils content in leaves and inflorescences. According to a survey conducted by Pascual et al. (2001), several classes of organic compounds have already been isolated from these plants, including terpenes, phenolic acids, flavonones, iridoids, cumarin, alkaloids, and saponines. Despite the importance, the agronomic studies on Lippia remains incipient, even for those species with frequently collected and widely distributed. Among these Brazilian species poorly studied on its agronomic features, Lippia lasiocalycina Cham., L. insignis Moldenke, L. thymoides Mart. \& Schauer and L. bromleyana Moldenke occur in the semiarid region. Nevertheless, these species don't share the same distribution. Lippia bromleyana and L. insignis are endemic of State of Bahia on northeastern region of Brazil, occurring in the Caatinga and Cerrado (BFG, 2015). Both species are included in the official national list of species of flora threatened extinction, in the vulnerable category (BRASIL, 2014). On the other hand, L. thymoides occurs both on the State of Bahia and Minas Gerais, and finally, Lippia lasiocalycina Cham. are not endemic of Brazil, occupying several phytogeographic domains as Amazon, Caatinga, Cerrado, and the Atlantic Forest (BFG, 2015). 
Lippia thymoides, popularly known as alecrim-do-mato, presents a 2\% yield of essential oil and thymol is its main component, its leaves infusion is used to control skin infections in baths (FUNCH et al. 2004). However, the essential oils chemical composition of L. insignis, L. lasiocalycina and $L$. bromleyana, or the description of their biological activity, were not known. According to Ramos et al. (2008), many Brazilian native species with medicinal properties are under threat of extinction; this situation continues to worsen over the years and is motivated by a number of factors, such as their intensive popular use, commercialization of the plants products, particularly in the northeast of Brazil, and as a result of deforestation and fires.

Although they represent a genetic resource with both medicinal and economic potential, the studies are still scarce, particularly regarding the species characterization and identification of agronomic and morphological descriptors, due to the difficulties in the identification of the species level. The morphological and agronomic characterization will allow the selection of the most promising species for cultivation, especially those with superior features related to the productivity of essential oil and their major components, and will contribute to the conservation of this important genetic resource. We stress that the taxonomic delimitation of Lippia is challenging due to the elevated number of described taxons, including species, varieties and forms without a defined infrageneric classification scheme (SALIMENA, 2002).

The objective of this study is to characterize, both from the morphological and agronomic perspectives, four species of Lippia collected in the semi-arid region of Bahia and to identify some descriptors to subsidize future breeding programs.

\section{MATERIAL AND METHODS}

\section{Horticultural practices}

The experiment was conducted with four (4) species of the genus: Lippia: L. insignis, $L$. bromleyana and L. thymoides, collected in State of Bahia, in the municipality of Morro do Chapéu, and L. lasiocalycina, in the municipality of Santa Terezinha. Herbarium specimens were kept on Herbarium HUEFS (Herbarium of Universidade Estadual de Feira de Santana) and are registered with the numbers: HUEFS 193480 (L. insignis), HUEFS 193481 (L. lasiocalycina) HUEFS 77554 (L. thymoides), and HUEFS 212549 (L. bromleyana).

The species were multiplied by clonal propagation by cutting. The cuttings were obtained from herbaceous shoots with approximately $15 \mathrm{~cm}$ long, using the commercial substrate biomix ${ }^{\circledR}$. The 
seedlings were grown in styrofoam trays with 128 cells, and kept for 45 days in plastic mini-greenhouse with intermittent fogging of 2 minutes, at intervals of 1 hour and 30 minutes, giving a total of eight sprayings per day. After 45 days of the planting, the seedlings were transferred to $10 \mathrm{x} 25 \mathrm{~cm}$ black polyethylene bags, filled with a mixture of organic compost and vegetable earth (1:1), and single superphosphate fertilizer $\left(18 \%\right.$ of $\left.\mathrm{P}_{2} \mathrm{O}_{5}\right)$ at the proportion of $1 \mathrm{~kg}$ per $\mathrm{m}^{3}$ of mixture, and were kept in a greenhouse with daily irrigations for 30 days. After an acclimatization period, the seedlings were planted in $20 \times 20 \times 20 \mathrm{~cm}$ holes, spaced every $50 \mathrm{~cm}$. The soil was fertilized with organic compost 15 days before the planting with cow manure (0.5 liters per hole) and phosphate fertilizer ( 15 grams of single superphosphate per linear meter of furrow). Throughout the experiment, the soil was hewed every two weeks.

\section{Morphological and agronomic characterization}

The qualitative morphological characterization followed the terminology proposed by Gonçalves and Lorenzi (2010) and was conducted 120 days after transplanting the seedlings to their final location. The leaves and inflorescences were analyzed with a binocular stereo microscope (Diagtech), to establish the growth habit, the branch type, the limb characteristics (shape, apex, base, edge, venation, pilosity), the color and shape of bracts, type and position of inflorescences, the perianth type, and the color of petals. The quantitative morphological characterization evaluated plant height $(\mathrm{m})$, stem diameter $(\mathrm{mm})$, canopy diameter $(\mathrm{m})$, leaf length $(\mathrm{cm})$, leaf width $(\mathrm{cm})$, leaf length/width ratio, leaf fresh weight $(\mathrm{g})$, petiole size $(\mathrm{cm})$, pedicel size $(\mathrm{cm})$, bract size $(\mathrm{cm})$, number of flowers per inflorescence and number of inflorescences per plant. After 170 days of the transplantation, the plants were harvested at approximately $15 \mathrm{~cm}$ above the ground to quantify the biomass and the essential oil production. The following characters were evaluated: fresh (g) and dry (g) biomass of inflorescences, leaves and stems, essential oil content $(\%)$, and essential oil yield, expressed in $\mathrm{kg}$ of oil per hectare. The biomass was dried in oven with forced air ventilation at $60^{\circ} \mathrm{C}$ for the stem and $30^{\circ} \mathrm{C}$ for inflorescences and leaves, until constant weight. After drying, the material was ground in a Willey mill.

\section{Essential oil production}

The species were harvested at 9:00 am. The extraction of essential oil was performed through hydrodistillation in a Clevenger apparatus, from $50 \mathrm{~g}$ of dry leaf biomass in $1000 \mathrm{~mL}$ of water kept for 3 
hours after the onset of steam condensation. The hydrolate obtained was dried with anhydrous sodium sulfate and stored in freezer.

\section{Experimental design and statistical analysis}

The experimental design was carried out in randomized blocks (DBC), with four repetitions (four plants per repetition, making a total of 16 plants per species) for each species of Lippia (L. insignis, L. thymoides, L. bromleyana and L. lasiocalycina). The data were submitted to variance analyses and the means were compared by Tukey's test at 5\% error probability, using the SISVAR statistical program (FERREIRA, 2011).

\section{RESULTS AND DISCUSSION}

We detected morphological differences in phyllotaxis, leaf venation and leaf edge among the species. Opposite and craspedrodomous leaves occur for L. insignis, L. lasiocalycina and L. bromleyana (Figures 1a, i, n and s, respectively), while lanceolate, verticillate and hiphodromous leaves were found for L. thymoides (Figure 1p, s). The bracts also presented visible differences on format, size and pilosity (Figures 1c, h, m, r). The species L. insignis, L. lasiocalycina and L. bromleyana presented petiole pilosity whereas L. thymoides lacked this feature (Figure 1e, j, o). In addition to these differences, we describe different sizes of inflorescence pedicels among the species, and L. thymoides was sessile (Figure 1b, g, $1, q)$. These characters are important to differentiate the species, and represent important tools for future genetic improvement works, aiming to increase the essential oil yield.

In the qualitative morphological evaluation, all four studied species presented shrub growth habit, erect branches and discolored leaves with the absence of stipules.

With the exception of $L$. thymoides, which presents lanceolate, verticillate and hiphodromous, the other species presented ovate, opposing and craspedrodomous (Table 1). The petals have different shades of purple: dark purple for L. insignis and L. lasiocalycina, and light purple for L. bromleyana and $L$. thymoides; the color of the bracts also differ: green for L. insignis and light green for the other species. 


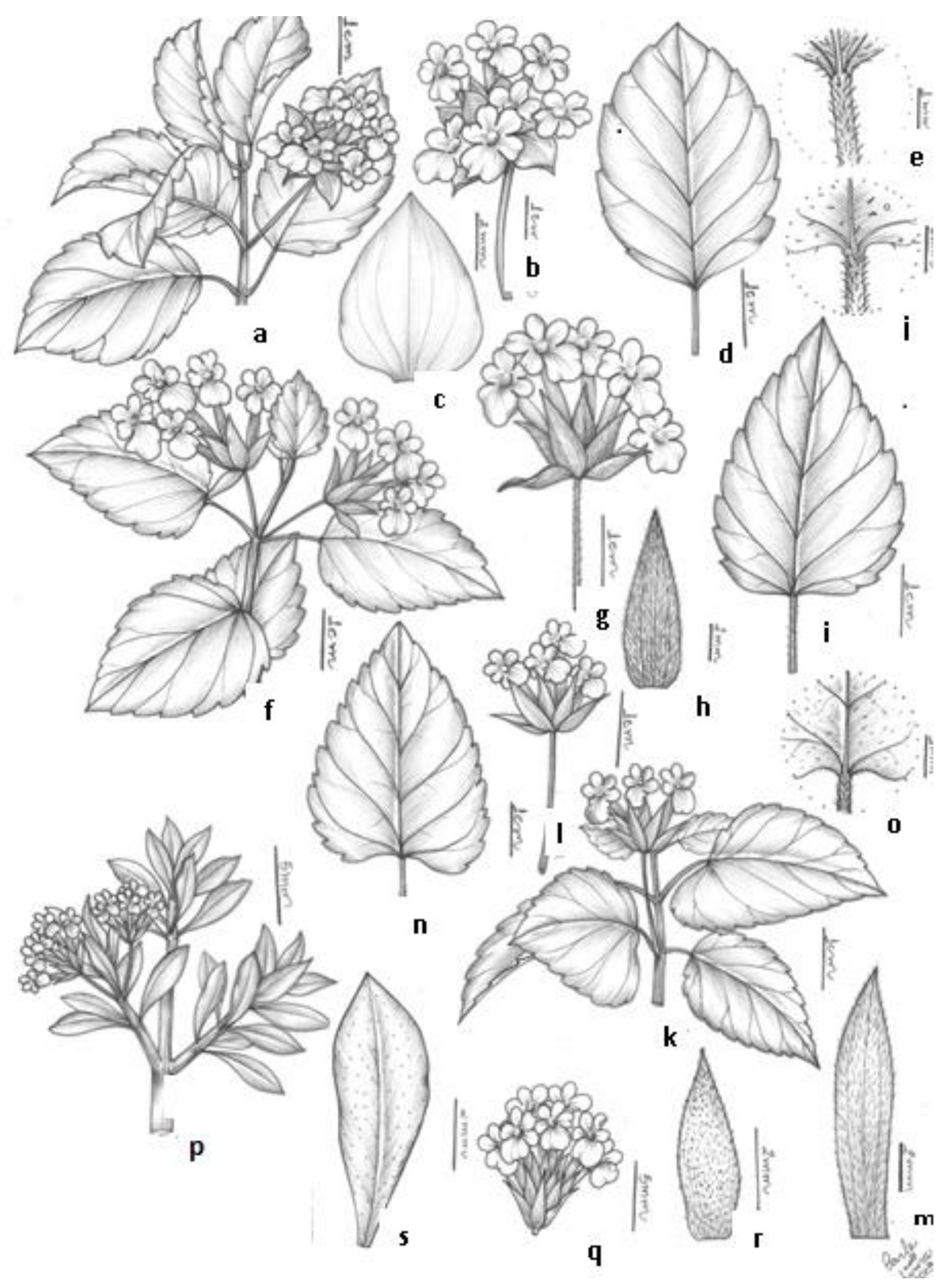

Figure 1. Lippia insignis: $\mathrm{a}=$ branch, $\mathrm{b}=$ inflorescence, $\mathrm{c}=$ bract, $\mathrm{d}=$ leaf, $\mathrm{e}=$ petiole. Lippia lasiocalicyna: $\mathrm{f}=$ branch, $\mathrm{g}=$ inflorescence, $\mathrm{h}=$ bract, $\mathrm{i}=$ leaf, $\mathrm{j}=$ petiole. Lippia bromleyana: $\mathrm{k}=$ branch, $\mathrm{l}=$ inflorescence, $\mathrm{m}=$ bract, $\mathrm{n}=$ leaf, $\mathrm{o}=$ petiole. Lippia thymoides: $\mathrm{p}=$ branch, $\mathrm{q}=$ inflorescence, $\mathrm{r}=$ bract, $s=$ leaf. 
Table 1. Growth habit (GH), ramification type (RT), limb format (LF), base format of the limb (BFL), apex format of the limb (AFL), limb margin (LE), venation (VN), consistency (CS), phyllotaxis (FT), petiole pilosity (PP), bracts color (BC), bracts format (BF), inflorescence type (IT), inflorescences position (IP), petals color (PC), perianth type (PT), trichomes in the abaxial face $(\mathrm{TABF})$, and trichomes in the adaxial face (TADF) in four native species of Lippia occurring in the semi-arid region of Bahia.

\begin{tabular}{ccccc}
\hline & L. insignis & L. thymoides & L. bromleyana & L. lasiocalycina \\
\hline GH & shrub & shrub & shrub & shrub \\
RT & erect branches & erect branches & erect branches & erect branches \\
LF & ovate & lanceolate & ovate & ovate \\
BFL & truncate & decurrent & decurrent & truncate \\
AFL & rounded & rounded & attenuated & attenuated \\
LE & crenated & entire & crenated & crenated \\
VN & craspedrodomous & hiphodromous & craspedrodomous & craspedrodomous \\
CS & coriaceous & membranous & chartaceous & membranous \\
FT & opposite & verticillate & opposite & opposite \\
PP & pilose & - & glabrous & pilose \\
BC & green & light green & light green & light green \\
BF & lanceolate & ovate & elliptic & Ovate \\
IT & racemose & racemose & racemose & racemose \\
IP & axillary & axillary & axillary & axillary \\
PC & purple & light purple & light purple & purple \\
PT & labiate & labiate & labiate & labiate \\
TABF & incano & glabrous & incano & pubescent \\
TADF & pilose & incano & glabrous & pilose \\
\hline
\end{tabular}

$(-)=$ not verified

The characteristics observed here in L. thymoides are similar to those described by Melo et al., (2010), for a specimen collected at "Estação Raso da Catarina", Bahia, except for the petiole. Among the species studied, L. thymoides is the most easily distinguishable in terms of morphology. The external morphological characters observed here for this species agree with the information provided by Salimena \& Silva (2009) regarding the genus. Some characteristics are common to all studied species, such as the growth habit, ramification type, inflorescence type and position, and the perianth type (Table 1).

We found significant differences for the quantitative morphological characters among the species (Table 2), except for the number of flowers per inflorescence. Lippia insignis and L. lasiocalycina were the tallest plants, reaching an average of $1.19 \mathrm{~m}$ and $1.16 \mathrm{~m}$, respectively, statistically different from the two other species. Although L. insignis and L. lasiocalycina present a number of similarities, the analyzed 
morphological characters were able to differentiate these two species. L. lasiocalycina presents the highest values of the evaluated characteristics, with exception of the number of inflorescences per plant, that is three times higher in L. insignis, and pedicel size, that is statistically smaller $(2.27 \mathrm{~cm})$ in comparison to L. insignis $(2.90 \mathrm{~cm})$. Lippia thymoides presents the lower average values of the morphological characters evaluated. These results confirm the description provided by Salimena and Silva (2009). Although L. thymoides presents a larger number of inflorescences per plant (27) in comparison to L. bromleyana (5) (Table 2), both species present similar weights of fresh and dry inflorescences, because the L. thymoides inflorescences are smaller. Lippia bromleyana presents intermediate values in comparison to the other species.

Table 2. Plant height (PH), stem diameter (SD), canopy diameter (CD), leaf length (LL), leaf width (LW) and leaf length/width ratio (L/W), leaf weight (LWE), petiole size (PS), pedicel size (PDS), bract size $(\mathrm{BS})$, number of flowers per inflorescence $(\mathrm{F} / \mathrm{I})$, and number of inflorescence per plant $(\mathrm{I} / \mathrm{P})$ in four native species of Lippia of the semi-arid region.

\begin{tabular}{cccccc}
\hline & L. inisgnis & L. lasiocalycina & L. thymoides & L. bromleyana & ${ }^{*} \mathrm{CV}$ \\
\hline PH (m) & $1,19 \mathrm{a}$ & $1,16 \mathrm{a}$ & $0,51 \mathrm{~b}$ & $0,56 \mathrm{~b}$ & 14,01 \\
$\mathrm{SD}(\mathrm{mm})$ & $6,37 \mathrm{~b}$ & $7,49 \mathrm{a}$ & $2,24 \mathrm{c}$ & $5,91 \mathrm{~b}$ & 9,29 \\
$\mathrm{CD}(\mathrm{m})$ & $0,69 \mathrm{~b}$ & $0,93 \mathrm{a}$ & $0,66 \mathrm{~b}$ & $0,25 \mathrm{c}$ & 4,39 \\
LL (cm) & $3,47 \mathrm{~b}$ & $4,92 \mathrm{a}$ & $1,05 \mathrm{c}$ & $3,77 \mathrm{~b}$ & 9,21 \\
LW (cm) & $3,10 \mathrm{a}$ & $3,45 \mathrm{a}$ & $0,34 \mathrm{c}$ & $2,61 \mathrm{~b}$ & 13,49 \\
L/W (cm) & $1,16 \mathrm{~b}$ & $1,39 \mathrm{~b}$ & $1,45 \mathrm{a}$ & $3,13 \mathrm{~b}$ & 11,95 \\
LWE (g) & $0,26 \mathrm{~b}$ & $0,35 \mathrm{a}$ & $0,01 \mathrm{c}$ & $0,26 \mathrm{~b}$ & 17,89 \\
PS (cm) & $1,45 \mathrm{a}$ & $1,55 \mathrm{a}$ & $0,00 \mathrm{c}$ & $0,92 \mathrm{~b}$ & 14,64 \\
PDS (cm) & $2,90 \mathrm{a}$ & $2,27 \mathrm{c}$ & $0,00 \mathrm{~d}$ & $2,60 \mathrm{~b}$ & 5,70 \\
BS (cm) & $0,6 \mathrm{a}$ & $0,5 \mathrm{a}$ & $0,2 \mathrm{~b}$ & $0,5 \mathrm{a}$ & 16,28 \\
F/I & $12 \mathrm{a}$ & $12 \mathrm{a}$ & $12 \mathrm{a}$ & $12 \mathrm{a}$ & 7,22 \\
I/P & $65 \mathrm{a}$ & $20 \mathrm{~b}$ & $27 \mathrm{~b}$ & $5 \mathrm{c}$ & 15,06
\end{tabular}

*CV= Coefficient of variation. Averages followed by different letters in the line differ by Tukey's test at 5\% probability of error $(\mathrm{p}>0,05)$. 
Morphological characters have been used effectively to distinguish plant species, and even variations within the same species, such result obtained by Jezler et al. (2013) who observed significant differences in the morphological leaf area and plant size in two morphotypes Lippia alba. The coefficient of variation $(\mathrm{CV})$ ranged from $4.39 \%$ to $16.28 \%$, depending on the variable analyzed. This range is acceptable for field experiments (GOMES, 2000) and suggests a high morphological variation within species. Other works with this same approach have shown similar coefficients of variation for other species (JANNUZZI et al. 2010; CAMELO et al. 2011).

Regarding the agronomic characteristics, we found significant differences for all evaluated characters (Table 3), according to Tukey's test at $5 \%$ error probability.

Table 3. Fresh weight of leaf biomass (FWLB), fresh weight of stem (FWS), fresh weight of inflorescences (FWI), dry weight of leaf biomass (DWLB), dry weight of stem (DWS), dry weight of inflorescences (DWI), essential oil content (EOC), and essential oil yield (EOY) in four native species of Lippia of the semi-arid region of Bahia: Lippia insignis (LI), Lippia lasiocalycina (LL), Lippia thymoides (LT), Lippia bromleyana (LB).

\begin{tabular}{|c|c|c|c|c|c|}
\hline & L. insignis & L. lasiocalycina & L. thymoides & L. bromleyana & $* \mathrm{CV}$ \\
\hline FWLB (g) & $105,4 b$ & $263,5 a$ & $74,5 b$ & $107,3 b$ & 16,9 \\
\hline FWS (g) & $129,8 b$ & $212,6 a$ & $46,6 \mathrm{c}$ & $41,9 \mathrm{c}$ & 23,9 \\
\hline FWI (g) & $67,9 a$ & $34,1 b$ & $12,9 \mathrm{c}$ & $13,0 \mathrm{c}$ & 15,9 \\
\hline DWLB $(\mathrm{g})$ & $31,1 b$ & $83,9 a$ & $22,5 b$ & $28,4 b$ & 18,5 \\
\hline DWS (g) & $50,7 b$ & $103,4 a$ & $17,3 \mathrm{c}$ & $14,9 \mathrm{c}$ & 20,4 \\
\hline DWI (g) & $14,4 \mathrm{a}$ & $7,5 b$ & $4,7 b$ & $4,0 \mathrm{~b}$ & 24,0 \\
\hline $\mathrm{EOC}(\%)$ & $0,99 \mathrm{ab}$ & $0,58 \mathrm{c}$ & $1,01 \mathrm{a}$ & $0,82 b$ & 9,3 \\
\hline EOY $\left(\mathrm{Kg} \cdot \mathrm{ha}^{-1}\right)$ & $18,0 \mathrm{a}$ & $21,5 \mathrm{a}$ & $10,8 b$ & $10,6 b$ & 22,2 \\
\hline
\end{tabular}

The higher production of inflorescences is a distinguished characteristic of Lippia insignis, with statistical significance. On the other hand, the production of leaf and stem biomass was higher for the species L. lasiocalycina. The essential oil content and yield varied significantly (Table 3). Lippia thymoides, L. insignis and L. bromleyana produced the highest contents of essential oil while Lippia 
lasiocalycina's production represented a reduction of $24 \%, 41 \%$ and $43 \%$ in comparison to $L$. bromleyana, L. insignis and L. thymoides, respectively.

Differences in production of leaf biomass and in essential oil yield have been verified even among accesses of the same species, as observed for Lippia alba, which presented significant differences for leaf dry biomass, and essential oil content and yield (CAMELO et al. 2011; JANNUZZI et al. 2011). The essential oil content is a genetically determined trait calculated in reference to $100 \mathrm{~g}$ of dry biomass; however, environmental factors can change the amount and quality of the essential oil produced by an aromatic species. Research data show a large variation on the essential oil content in Lippia species based on the dry biomass, varying from $0.09 \%$ to $2.80 \%$ for Lippia alba (CAMELO et al. 2011; JANNUZZI et al. 2010; and JANNUZZI et al. 2011), 0.60\% to 1.44\% for Lippia citriodora (SOUZA et al. 2010); and $3.47 \%$ to $4.33 \%$ for Lippia sidoides (CHAVES et al. 2008). These differences occur not only between different species, but within the same species cultivated in different conditions.

Despite presenting the lowest essential oil content, Lippia lasiocalycina had the highest essential oil yields, along with Lippia insignis, significantly superior to Lippia thymoides and Lippia bromleyana. This is because this parameter is directly related to the amount of biomass produced. Lippia lasiocalycina produced the largest amount of dry leaf biomass. However, although the essential oil content and yield are important agronomic parameters, the chemical composition must be considered as the commercial value of essential oils arises from the type and percentage of the main components.

\section{CONCLUSION}

Morphological and agronomic variations were found among species of Lippia studied, which allows to distinguish them; Lippia lasiocalycina and L. insignis are distinguished by the higher production of biomass and higher essential oil yield.

\section{REFERENCES}

BRASIL, Ministério do Meio Ambiente. 2014. Portaria N. 443, de 17 de dezembro de 2014. Brasília, DF, 2014. Available at: http://cncflora.jbrj.gov.br/portal/static/pdf/portaria_mma_443_2014.pdf. Access in: October $14^{\text {th }}, 2016$.

CAMELO L. C. A.; BLANK, A. F.; EHLERT, P. A. D.; CARVALHO, C. R. D.; ARRIGONI-BLANK, M. F \& MATTOS, J. 2011. Caracterização morfológica e agronômica de acessos de erva-cidreirabrasileira [Lippia alba (Mill.) N. E. Br.]. Scientia Plena, Aracajú, v.7, p. 1-8. 
CHAVES, F. C. M.; MATTANA, R. S.; GONÇALVES, M. A.; MATOS, F. J. A.; FREIRE, A. M. R.; BIZZO, H. R.; ANGELO, P. C. MING, S. C \& BOTELHO, J. B. L. R. 2008. Teor de óleo essencial e seus constituintes em alecrim pimenta (Lippia sidoides) de três regiões geográficas distintas. Horticultura Brasileira, Vitória da Conquista, v. 26, p.1462-1465.

FERREIRA, D. F. 2011. Sisvar: A computer statistical analysis system. Ciência e Agrotecnologia, Lavras v. 35, p. 1039-1042.

FUNCH, L. S.; HARLEY, R.; FUNCH, R.; GIULIETTI, A. M \& MELO, E. 2004. Plantas úteis: Chapada Diamantina. São Carlos: Rima, 216 p.

GONÇALVES, E. G \& LORENZI, H. 2010. Morfologia Vegetal. Organografia e dicionário ilustrado de morfologia das plantas vasculares. $2^{\mathrm{a}}$ ed. São Paulo: Instituto Plantarum de Estudos da Flora.

JANNUZZI, H. MATTOS, J. K. A.; SILVA, D. B.; GRACINDO, L. A. M.; VIEIRA, R. F. 2011. Avaliação agronômica e química de dezessete acessos de erva-cidreira [Lippia alba (Mill.) N.E.Brown] - quimiotipo citral, cultivados no Distrito Federal. Revista Brasileira de Plantas Medicinais, Botucatu, v.13, p.258-264.

JANNUZZI, H.; MATTOS, J. K. A.; VIEIRA, R. F.; SILVA, D. B.; BIZZO, H. R \& GRACINDO, L. A. M. 2010. Avaliação agronômica e identificação de quimiotipos de erva cidreira no Distrito Federal. Horticultura Brasileira, Vitória da Conquista, n. 28, p.412-417.

JEZLER, C.N.; OLIVEIRA, A. R. M. F.; BATISTA, R. S.; OLIVEIRA, R. A.; SILVA, D. C. S.; COSTA, L. C. B. 2013. Lippia alba morphotypes cidreira and melissa exhibit significant differences in leaf characteristics and essential oil profile. Brazilian Journal of Pharmacognosy, v. 23, p. 217-223.

MELO, J. I.; ALVES, I. M.; SOUSA, R. T. M.; BARBOSA, L. M. M. A.; ANDRADE, W. M. 2010. Verbenaceae sensu lato em um trecho da ESEC Raso da Catarina, Bahia, Brasil. Revista Caatinga, Mossoró, v. 23, p. 41-47.

O’LEARY, N.; DENHA, S. S.; SALIMENA, F.; MÚLGURA, M. E. 2012. Species delimitation in Lippia section Goniostachyum (Verbenaceae) using the phylogenetic species concept. Botanical Journal of the Linnean Society, Londres, v. 170, p. 197-219.

PASCUAL, M. E.; SLOWING, K.; CARRETERO, E.; SÁNCHEZ MATA, D.; VILLAR A. 2001. Lippia: traditional uses, chemistry and pharmacology: a review. Journal of Ethnopharmacology, Irlanda, v. 76, p. 201-214.

GOMES, F. P. 2000, Curso de estatística experimental. 14 ed. Piracicaba, Degaspari, 477p.

RAMOS, S. S. S; QUEIROZ, M. A. de; ROMÃO, R. L.; SILVA JÚNIOR, J. F. da. 2008. Germoplasma vegetal conservado no nordeste brasileiro: situação atual, prioridades e perspectivas. Magistra, Cruz das Almas, v. 20, p. 205-217.

BFG, 2015. Growing knowledge: an overview of Seed Plant diversity in Brazil. The Brazil Flora Group. Rodriguésia, v. 66, n.4, p.1085-1113.

SALIMENA, F. R. G. 2002. Novos sinônimos e tipificações em Lippia sect. Rhodolippia (Verbenaceae). Darwiniana, Buenos Aires, v. 40, p. 121-125.

SALIMENA, F. R. G.; SILVA, T. R. S. 2009. Flora de Grão-Mogol, Minas Gerais: Verbenaceae. Boletim Botânico da Universidade de São Paulo, São Paulo, v. 27, p. 119-120.

SOUZA, M. F.; SOUZA JUNIOR, I.T; GOMES, P.A.; FERNANDES, L.A.; MARTINS, E.R.; COSTA, C.A.; SAMPAIO, R.A. 2010. Calagem e adubação orgânica na produção de biomassa e óleo essencial em Lippia citriodora Kunth. Revista Brasileira de Plantas Medicinais, Botucatu, v.12, p. 401-405. 